UNITED STATES DEPARTMENT OF THE INTERIOR

GEOLOGICAL SURVEY

A DESCRIPTION OF COLORED GRAVITY AND TERRAIN MAPS

FOR THE CONTERMINOUS UNITED STATES,

SHOWN ON 35-mm SLIDES

by

R. W. Simpson, T. H. Hildenbrand, R. H. Godson, and M. F. Kane

Open-File Report $82-477$

1982

This report is preliminary and has not been reviewed for conformity with U.S. Geological Survey editorial standards.

Any use of trade names is for descriptive purposes only does not imply endorsement by the USGS. 
A Description of Colored Gravity and Terrain Maps

For the Conterminous United States,

Shown on $35-\mathrm{mm}$ S1ides

by

R.W. Simpson, T.H. Hildenbrand, R.H. Godson, and M.F. Kane

INTRODUCTION

Over the past several years the U.S. Geological Survey has produced a series of regional geophysical syntheses for various programs including earthquake hazards, reactor hazards, geothermal energy, radioactive waste repository sites studies and wilderness studies. These syntheses required the compilation and editing of gravity-data files covering large parts of the country and the development of many daughter products such as wavelengthfiltered, gradient, and derivative maps. We combined these data with other gravity and terrain data available to us for the conterminous United States and developed the maps described herein. These colored maps may be obtained as standard 2" $x 2$ " color s1ides from the U.S. Geological Survey Photo Library (Mail Stop 914, Box 25046, Denver Federal Center, Denver, C0, 80225, telephone 303/234-4004). Plans are underway to produce them in finished form as colored Geophysical Investigations Maps at their original scale of 1:7,500,000.

THE DATA SETS

1. Gravity Data

The bulk of the gravity data were extracted from the U.S. Department of Defense (DOD) gravity-data file available through the U.S. National Oceanic and Atmospheric Administration (NOAA) Data Center. (NOAA, National Geophysical and Solar Terrestrial Data Center, Boulder, CO 80302). Other data sets which were assembled for various studies have been added to this NOAA file. Additional gravity data in the Great Lakes area were kindly provided by the Canadian Gravity Data Centre (Energy, Mines and Resources of Canada, Earth Physics Branch, Gravity and Geodynamics Division, 1 Observatory Crescent, Ottawa, Canada, K1A OY3).

The United States on-land gravity stations have been terrain corrected from $167 \mathrm{~km}$ a distance of $0.895 \mathrm{~km}$ from the station using a computer program of Plouff (1977). We belleve the inner zone corrections, which we have omitted, to be insignificant for probably 99 percent of the stations. That is, the inner corrections are expected to be substantially less than the 2-milligal uncertainty which we estimate for the majority of the land observations. Some mountainous areas do have inner zone corrections in excess of 2 milligals, but we do not expect that our neglect of these corrections will change the regional anomaly patterns in any significant way at this scale $(1: 7,500,000)$.

Even after much editing, some bad data points are still apparent-especially in the gradient plots where they produce small four-petal flower patterns. Questions about single small anomalies should be referred to larger scale maps and to the original published maps where these are available. 
The data set was first screened at a $4-\mathrm{km}$ interval by selecting only one station per $4-\mathrm{km} \times 4-\mathrm{km}$ cell where data were available. This screening reduced the number of stations used to 221,215 . The choice of a 4-km cell size was a compromise between using as much data as possible, and yet not biasing the final display by wide variations in data density.

A minimum curvature algorithm (Briggs, 1974) programmed by Webring (1981) was then used to do the necessary interpolation and extrapolation to produce a rectangular grid of values with approximately $6-\mathrm{km}$ intervals between grid points.

In order to reduce edge effects, the original grid was approximately $60 \mathrm{~km}$ larger on all sides before it was trimmed to the present size. Possible edge effects may still appear on certain filtered maps in the form of $\mathrm{N}-\mathrm{S}$ or $\mathrm{E}-\mathrm{W}$ anomalies paralleling the edges of the map, however, and the user should be aware of this problem.

The data were projected using the Albers Conic Equal-Area projection with standard parallels for the United States $\left(29.5^{\circ} \mathrm{N}, 45.5^{\circ} \mathrm{N}\right)$, so that the maps are compatible in projection with other national geologic maps.

\section{Terrain Data}

Terrain data were obtalned from the U.S. National Geodetic Survey (NGS) who in turn received it from the Electromagnetic Compatability Analysis Center (ECAC), an agency of the U.S. Department of Defense (DoD). The data were extensively edited and reformatted (by R. H. Godson) to produce average elevations for the entire country at 30second, 1-minute and 3-minute intervals. This data set has been submitted to the NOAA Data Center (National Geophysical and SolarTerrestrial Data Center, National Oceanic and Atmospheric Administration, Boulder, CO 80303) for distribution.

DESCRIPTION OF THE MAPS

1. Station Plot Map

This map shows the 221,215 stations in the screened data set used to produce the colored maps.

2. Bouguer Long-Wavelength Reglonal $(>1000 \mathrm{~km})$ (color interval $=10$ milliga1s)

Using a Fourier transform filtering program wavelengths less than 1000 $\mathrm{km}$ in the Bouguer anomaly fleld were suppressed. (A ramped low pass filter was used with a ramp between $900 \mathrm{~km}$ and $1100 \mathrm{~km}$ ) ) This has the effect of extracting a regional field consisting of the broader features of the gravity field.

3. Bouguer Short-Wavelength Residual $(<1000 \mathrm{~km})$ (color interval = 5 mi11iga1s) 
By subtracting the long-wavelength regional from the original Bouguer gravity field, we produced the complementary short-wavelength residual map in which wavelengths greater than $1000 \mathrm{~km}$ have been removed.

Wavelength filtering can produce spurious anomalies flanking real anomalies (Ulyrch, 1968). In general, a linear high will be flanked by two lower amplitude parallel lows, which in turn are flanked by two parallel highs (of very much smaller amplitude than the original). This condition may produce a grain roughly equal in wavelength to the cut of the filter. Thus, all parallel, linear anomalies should be interpreted with care. This problem, however, is more than compensated for by the enhancement of many structures and features of geologic interest.

4. Bouguer Long-Wavelength Regional $(<250 \mathrm{~km})$ (color interval = 10 milligals) This map was produced in the same fashion as \# , except that a cut of $250 \mathrm{~km}$ with a ramp from $200 \mathrm{~km}$ to $300 \mathrm{~km}$ was used.

5. Bouguer Short-Wavelength Residual $(<250 \mathrm{~km}$ ) (color interval $=5$ milligals) Similar to $\$ 3$ except that wavelengths greater than $250 \mathrm{~km}$ have been suppressed.

6. Bouguer Short-Wavelength Residual $(<125 \mathrm{~km})$ (color interval = $5 \mathrm{milligals}$ ) Simflar to $\$ 3$ except that wavelengths greater than $125 \mathrm{~km}$ have been suppressed.

7. Wavelength Band-Pass of Bouguer Gravity $(250 \mathrm{~km}$ to $1000 \mathrm{~km}$ ) (color interval $=10$ milligals)

Similar to both \#3 and \#4 in that wavelengths greater than $1000 \mathrm{~km}$ and less than $250 \mathrm{~km}$ have been supressed.

8. Horizontal Gradient of the Bouguer Gravity (color interval $=0.1 \mathrm{mgal} / \mathrm{km}$ ) The magnitude of the horizontal gradient of the Bouguer anomaly field was calculated using the basic equation:

$$
\mid \text { gradient } \mid=\left(\frac{\partial z}{\partial x}\right)^{2}+\left(\frac{\partial z}{\partial y}\right)^{2}
$$

and the approximations that

$$
\left(\frac{\partial z}{\partial x_{i, j}}\right)_{i=\frac{z_{i+1, j}-z_{i-1, j}}{2(\Delta x)} \text {, and }\left(\frac{\partial z}{\partial y_{i, j}}\right)_{i, j+1}-z_{i, j-1}}^{2(\Delta y)} \text {, }
$$

where $x$ is the latitudinal coordinate, $y$ is the longitudinal coordinate, and $z$ is the gravity value.

This approximation can be shown to be equivalent to fitting a parabola at grid-point 1 using $z_{1}$ and its two neighboring values $z_{i+1}, z_{1-1}$ and 
then calculating the slope of the parabola at 1 . The magnitude of the gradient of an anomaly depends on both the size of the density contrast and the nearness of the source to the surface. The largest gradients will commonly occur nearly over the mass contrast at the edges of geologic bodies. Cordell (1979) has used the horizontal gradient to locate faults. Note, however, that the steepest gradients produced by an ideal point source at depth or an equivalent spherical source do not relate as directly to the physical extent of the body.

Horizontal gradients produced by linear anomalies are steepest over the two sides and gentle or flat along the tops of the anomalies so that there are two flanking high gradients and a medial low gradient. More equidimensional anomalies have their highest gradients circling them. The result on the color map is a red doughnut encircling the anomaly.

Many of the circular and highly curved gradients mark the mapped contacts of felsic and mafic plutons, suggesting that other similar gradients showing no correspondence with surface geology mark buried plutons.

9. Terrain (nonlinear color intervals $=100,250$, or $500 \mathrm{~m}$ )

Elevation data spaced on a grid with a 3 second interval were used as the basic data set. The data were projected (Albers) and regridded to a $6-\mathrm{km}$ interval to produce a map at a scale of $1: 7,500,000$ on the color plotter. A differently colored version of this map has already been published (Godson, 1981).

10. Slope of Terrain (nonlinear color intervals $=3,5,10,20,30 \mathrm{~m} / \mathrm{km}$ ) The magnitude of the slope for each $6-\mathrm{km}$ grid cell of the terrain data was calculated with the following equation:

$$
\text { slope }=\left(\frac{\Delta z}{\Delta x}\right)^{2}+\left(\frac{\Delta z}{\Delta y}\right)^{2}
$$

where $x$ is the latitudinal coordinate, $y$ is the longitudinal coordinate, $z$ is the elevation, and as before,

$$
\frac{\Delta z}{\Delta x}=\frac{z_{i+1, j}-z_{i, j}}{\Delta x} \text { and } \frac{\Delta z}{\Delta y}=\frac{z_{i, j+1}-z_{i, j}}{\Delta y} \text {. }
$$

11. Terrain Long-Wavelength Regional $(>1000 \mathrm{~km})$ (color interval = $100 \mathrm{~m}$ ) This map was produced in the same fashion as \#2 to obtain regional topographic features of wavelengths of $1000 \mathrm{~km}$ or greater.

12. Terrain Short-Wavelength Residual $(<1000 \mathrm{~km})$ (Color interval $=50 \mathrm{~m}$ ) By subtracting the long-wavelength regional of 111 from the original terrain data, we produced the complementary short-wavelength residual map in which wavelengths greater than $1000 \mathrm{~km}$ have been removed. 
13. Terrain Long-Wavelength Regional $(>250 \mathrm{~km})$ (Color interval $=100 \mathrm{~m}$ ) This map was produced in the same fashion as \#4, where wavelengths 1ess than $250 \mathrm{~km}$ have been suppressed.

14. Terrain Short-Wavelength Residual $(<250 \mathrm{~km})$ (Color Interval = $50 \mathrm{~m}$ ) Similar to $\$ 12$ except that wavelengths greater than $250 \mathrm{~km}$ have been suppressed. 
Briggs, I. C., 1974, Machine contouring using minimum curvature: Geophysics, v. 39, p. 39-48.

Corde11, Lindrith, 1979, Gravimetric expression of graben faulting in Santa Fe Country and the Espanola Basin, New Mexico: New Mexico Geological Society Guidebook, 30th Field Conference, Santa Fe Country, p. 59-64.

Godson, R. H., 1981, Digital terrain map of the United States: U.S. Geological Survey Miscellaneous Investigations Map I-1318, scale $1: 7,500,000$.

Plouff, D., 1977, Preliminary documentation for a FORTRAN program to compute gravity terrain corrections based on topography digitized on a geographic grid: U.S. Geological Survey Open-File Report 77-534, 45 p.

Ulyrch, T. J., 1968, Effect of wavelength filtering on the shape of the residual anomaly: Geophysics, v. 33, p. 1015-1018.

Webring, M. W., 1981, MINC--gridding program based on minimum curvature: U.S. Geological Survey Open-File Report 81-1224. 